\title{
PE - 01 \\ THE EFFECTIVENESS USING OF CONTEXTUAL TEACHING MATERIAL INTEGRATING MATHEMATICS, NATURAL SCIENCE, DISASTERS AND CHARACTER BASE ON ICT IN PHYSICS LEARNING HIGH SCOOL GRADE XI
}

\author{
Akmam, Harman A, Asrizal, Dea. S, Widya. F \\ Physics Department Mathematics and Natural Sciences Padang State University \\ Email: akmam_db@fmipa.unp.ac.id
}

\begin{abstract}
Integration of knowledge that relevant to physics such as Mathematics, Technology, other Sciences, Disasters, and the human character (MSTDC) is important to be done to improve student learning outcomes in Physics. Taking of the above research and development learning materials by integrating MSTDC in the ICT to achieve student competencies in grade XI have conducted. Design this research is before-after experimental in order to get the effectiveness of the product. Instrument which was used namely validity and practicality sheets and student learning outcomes sheets in objective test. Analysis of the data showed as below. First, the learning material which is produced is well good categories in four aspects such as material substances, the display of visual communication, learning and use of software design. Second, integrating learning materials MSTDC on ICT for grade XI is valid with an average score of 84.62 by experts and 82.68 by practitioners of education. Coefficient correlation score pretest and posttest learning outcome $\left(\mathrm{r}_{\mathrm{xy}}\right)=0.31$. Based on the analysis of score of student learning outcomes and student attitude obtained correlated $\mathrm{t}_{\text {test }}$ respectively are 1.91 and 12.42 , while the critical value in t distribution table with degrees freedom of 120 and $5 \%$ significance level is 1.66 . We can concluded that contextual Physics learning materials that integrated MSTDC base on ICT effectively used in the learning process according to standards to improve learning outcomes and to improve the attitude of senior high school students in class XI.
\end{abstract}

Keywords: Teaching materials, physics, MSTDC, effectiveness

\section{Introduction}

Competitive human resources can be contributes to nation building. Activities that can be done to produce it are improving the quality of education. The government has made efforts to increase the quality of learning. One of activities which government does is the improvement of the curriculum into the curriculum in 2013. In curriculum 2013 for elementary school to secondary school emphasizes the competence of graduates of good human attitudes, has skills and knowledge related to the integrated learning materials including the use of technology in the form of ICT. Integrated skills and knowledge must be relevant to the competencies required. Emphasizes can be done by integrating a variety of concept and values of good human attitudes related to learning.

Quality learning is an important factor for achieving the goal of education to produce graduates competency in accordance with needs. According to the default of learning process, learning in the class should be conducted in interactive, inspiring, fun, challenging, motivating students to participate actively, and provide enough space for students to develop initiative, 
creativity, and independence ${ }^{[5],[14],[20]}$. So, students in this condition can construct knowledge, behaviors, and skills in the learning process by their self

One indicator of the success of the learning process is the increased quality of the graduates that formally indicated by graduates who can adapt to the environment and they have life skills and soft skills ${ }^{[3],[18]}$. In non-formal learning quality can be reflected by how far graduates have a scientific attitude as the character of the scientific community ${ }^{[20],[26],[36]}$. One way that can be taken to improve the quality of the graduates is improving the quality of learning and the arranged learning resources that can be accessed anytime and anywhere. To improved quality of service to students can be done by selecting the appropriate learning resources, so that students have a scientific attitude among others, honest, objective, open, skeptic, tolerant, creative and innovative. One of the learning resources that can be developed is instructional materials that integrate the competencies needed to live in a society in an eye relevant material.

Based on the observations which under taken when technical guidance in West Sumatra is found that implementation of learning physics in high school have not been directed to establish a comprehensive student competence. Implementation learning Physics is still partially so that less support student competency as a whole. Learning physics in this way is less useful by the students in real life. As a result, the interest and motivation of students towards learning physics is not optimum.

One alternative solution to overcome this problem is to develop contextual learning materials by integrating Math, Science, Technology, natural disasters, and noble character (MSTDC) base on ICT into the learning process by the standards of competence to form students. The integration of knowledge related to physics, relevant skills, understanding of the natural disasters, and good attitude character values into learning physics is important to develop in order to achieve complete student competence.

A contextual learning material which is integrating the MSTDC has several advantages. First, it supports the application of contextual learning by incorporating the real world into the learning process. Second, it can help the difficulties of students in solving physics problems due to limitations in Mathematics. Thirdly, it recognizes physical linkages with other branches of science and technology applications in physics. Fourth, give insight to the students about the natural phenomena that can cause natural disasters and how to behave towards the natural disaster. Fifth, support the use of ICT in learning physics.

Contextual learning material which is integrating the MSTDC is done by arranging priorities and finding skills in curriculum, concepts, and attitudes that related to another the objects used in the study are the priority assessment ${ }^{[5],[12],[16]}$. An integrated approach can be doing through scientific processes, organizing the natural integration of scientific knowledge and its application in daily life $\mathrm{e}^{[8],[15]}$. Integration concepts and value good behavior needs to be done in the natural sciences for students to understand natural phenomena around them.

Integration is merging and coordinating all the parts separately into a single unit. The purpose of integration is to improve the mastery and skills intact. Natural sciences like Physics, Chemistry, Biology and Technology are the two mutually interconnected with other. Technology will not be able to develop without natural science, on the other hand natural science requires technology to provide research facilities and equipment are accurate. For example, a steam engine will not be found in the absence of research in the physics. On the other hand, the success of the manufacture of steam engines is to encourage further research in the natural science that relevant to the theory of heat and thermodynamics ${ }^{[3], ~[4], ~[6] . ~ I n t e g r a t i o n ~}$ has two dimensions, namely horizontal integration and vertical integration. Mathematics is useful to understand earth phenomena. 
Mathematics in Physics plays an important role as the language of physics is mathematics [6]. There are three roles in mathematical physics, namely: mathematics as a symbol, mathematical as a concept maps, and mathematical as thinking in physics as the mechanism. Teachers cannot know what English/ mathematics/ICT used their learners as they move through their lives. This means that we cannot identify a core curriculum that every learner will use. Instead, and much more powerfully, learners should be taught to use and apply the English / mathematics / ICT that they know and to ask for help with the areas with which they are less confident ${ }^{[26]}$. Biology is a natural science concerned with the study of life and living organisms, function, growth, evolution and distribution. Modern biology is a vast and eclectic field, composed of many branches and sub disciplines. However, despite the broad scope of biology, there are certain general and unifying concepts within it that govern all study and research, consolidating it into single, coherent field. It is also understood today that all organisms survive by consuming and transforming energy and by regulating their internal environment to maintain a stable and vital condition. This is the physics of the phenomena of life are to learn all levels of molecules and cells to the biosphere as a whole ${ }^{[3]}$. This shows the relationship between physics with biology.

Chemistry, a branch of physical science, is the study of the composition, structure, properties and change of matter. Chemistry is chiefly concerned with atoms and their interactions with other atoms. As well as this, interactions including atoms and other phenomena - electrons and various forms of energy are considered. Chemistry is a branch of physical science but distinct from physics. Physics is the natural science that involves the study of matter and its motion through space and time, along with related concepts such as energy and force. Physics was a part of natural philosophy along with chemistry; certain branches of mathematics, and biology, the natural sciences emerged as unique research programs in their own right. Physics intersects with many interdisciplinary areas of research, such as biophysics and quantum chemistry, and the boundaries of physics are not rigidly defined. Physics also makes significant contributions through advances in new technologies that arise from theoretical breakthroughs ${ }^{[41]}$.

Physics also has a relationship with the natural disaster. Natural disaster is natural phenomena which it event difficult to predict. However, if the natural phenomenon hit man and all products cultivation (ownership, property and objects), this event we call it a disaster. A natural disaster is a major adverse event resulting from natural processes of the Earth that is occurs suddenly; examples include floods, volcanic eruptions, earthquakes, tsunamis, and other geologic processes. A natural disaster can cause loss of life or property damage, and typically leaves some economic damage in its wake, the severity of which depends on the affected population's resilience, or ability to recover a good understanding of the physics causing a good understanding of natural phenomena and natural disasters. In this way students better understand the natural disasters and have the mental readiness in the face of natural disasters, especially for areas that are prone to disasters such as earthquakes, tsunamis, floods, and so on.

Basically, value of character is quality of attitudes which show quality and useful humans in society. Educational value is a measure of character, quality, or content of a person's character or personality that can be nurtured and developed through education. Character education is the deliberate effort to help people understand, how about, and act upon core ethical values. When we think or the kind of character we want is right, care deeply about what is right, even in the face of pressure from without and temptation from within [21],[24],[35],[38]. Human who has Noble character (good attitudes) is an individual has the knowledge about her potential, which is characterized by how far they can self-evaluated as reflective, self-confident, rational, logical, critical, analytical, creative and innovative, independent, healthy living, 
responsible, love science, patient, careful, self-sacrificing, courageous, trustworthy, honest, keeping promises, fair, humble, forgiving, loyal, hard-working, persevering, tenacious/persistent, meticulous, initiative, positive thinking, discipline, anticipatory, initiative, visionary, dynamic, thrifty, appreciate the time, dedication, self-control, productive, friendly, sporty, resilient, etc. Individuals also have the awareness to do the best or superior, and able to act on the potential and consciousness. Characteristic is the realization of positive developments as well individual intellectual, emotional, social, ethical, and behavioral ${ }^{[21]}$. Individual who have good attitude (noble character) is someone who tried to do the best things to Allah, himself, their friends, the environment, the people and international society by optimizing the potential (knowledge) itself and accompanied by consciousness, emotion and motivation.

In fact, Physics learning activity in schools still have some problems. According to information and data from Dinas Kependidikan dan Kebudayaan Kota Padang West Sumatra, Kota Padang has 19 SMA/MA that have ICT system facilities that use for learning activity. However, these ICT facilities have not been use optimally. Learning materials that are used for instructional was a print out material. In addition, West Sumatra is prone region, while the knowledge of the population about natural disasters is still low. This condition is the potential to develop learning materials by integrating knowledge and skills relevant to the teaching of physics in schools. The lack of a good attitude to learning or noble character also becomes a problem in learning, so often we found students who violate the rules and norms. Integrating Mathematics, Science, technology, natural disasters, and noble character that later shortened to MSTBK becomes important. The importance of integrating MSTBK in learning physics because physics is not a science that stands alone but is also associated with other natural knowledge and skills relevant to our daily lives.

Based on the description the above, it is necessary to develop instructional materials Physics contextual that integrated MSTDC base on ICT. Therefore, research and development have been done to make learning materials of Physics that integrating MSTDC base on ICT that can be used as learning material in senior high school in class XI. For this reason research and development are carried out that purpose to determine the validity and the effectiveness contextual physics teaching material integrating MSTDC base on ICT on physics learning to achieve competency for student at Class XI Senior High School. To focus research, based on explained the above that has been formulated problem in this research. As the formulation of the problem of this research are:

1. How far validity descriptions of Physics Contextual Learning Materials that Integrated MSTDC base on ICT to achieve Competence physics student in Class XI Senior High School?

2. How far practicality and effectiveness of the use of Contextual Physics Learning Materials that Integrated MSTDC base on ICT into standard processes according to achieve Competence physics student in Class XI Senior High School?

\section{METHODS OF RESEARCH}

This type of research is research and development. Design of research is before and after design to test the effectiveness of these products. The procedure of this research is divided into two stages. The first stage, the activities directed towards to make of Physics contextual learning materials that integrated MSTDC base on ICT in order to have good validity. The 
second stage, the activities directed to use of Physics contextual learning materials that integrated MSTDC base on ICT. To try product in the learning process according to standards in senior high school in order to determine the practicality and effectiveness ${ }^{[27]}$. The design of instructional materials physics contextual that integrate MSTBK based ICT designed in accordance with the rules by the BNSP. After that, the design of products validated. Validation of the design is a process to assess whether the design of the product is valid or not. Validation of the product is done by experts and practitioners who are competent in assessing new product designed. Validation of the design is done with an assessment based on existing indicators in the assessment component. In this research, product design validation performed by five lecturers, State University of Padang and two physics teachers on senior high school. Once the product is validated, it is known weaknesses of the product. Researchers conducted design improvements based on the feedback given by the validated. The purpose of testing is to determine the practicality of the product and the effectiveness of the product. Testing of product is done in a limited sample, such as in SMAN 10 Padang and SMAN 3 Padang. In the process testing of product, researchers act as teachers who use products that have been validated by the validated.

In this research are used three kinds of data collection instruments. First, sheet validity for experts and practitioners, student's practicality sheets for practicality product, objective sheets test for learning outcomes, and observation character sheet for value of attitude (noble character). Sheet validity test is used to determine the validity of Physics contextual learning materials that integrated MSTDC base on ICT according to experts. Sheet practicality test used to determine feasibility of use of Physics contextual learning materials that integrated MSTDC base on ICT in learning. Sheet achievement test is used to determine the effectiveness of the use of Physics contextual learning materials that integrated MSTDC base on ICT in learning. Instrument validation is divided into two, namely the validity of the instrument for experts from lecture who review products resulting from the theoretical view and instrument validity for high school physics teachers are reviewing the product as practitioners teaching and learning in senior high school.

The data were analyzed by using four types of methods, namely descriptive statistical analysis, the method of graphs, linear regression and correlation analysis, and comparative analysis correlated. Descriptive analysis is used to find out more detailed information about the student learning outcomes data include: the value of the average, median, mode, deviation variance and so on. Graphic method is used to give a visual impression about the practicality of the use of Physics contextual learning materials that integrated MSTDC base on ICT in teaching and learning. Regression and correlation analysis of each is used to determine the relationship after learning the results of the pre-treatment and determine the value of the regression coefficients. Comparative analysis is used to determine the effectiveness correlates the use of Physics contextual learning materials that integrated MSTDC base on ICT. Products assessed using a questionnaire that was completed by experts. Scores were given expert analyzed to determine the level of validity of the product developed. Score that is giving by validated are converted by using a Likert Scale.

Comparative analysis is used to analyze the correlates of student learning outcomes before and after a given treatment. According to the results of data analysis will be known the effectiveness of Physics contextual learning materials that integrated MSTDC base on ICT. To prove the significance of differences in pretest and posttest results, need to be tested statistically by $\mathrm{t}_{\text {test }}$ correlated ${ }^{[27]}$. 


\section{RESULT OF RESEARCH AND DISCUSSION}

\section{a. Description of Product}

Teaching materials developed in accordance with the design that had been developed. Physics contextual learning materials that integrated MSTDC base on ICT include: the identity of the author, introduction, learning materials, evaluation, references, downloads chats and discussion forums. Display of the first page is as follow;

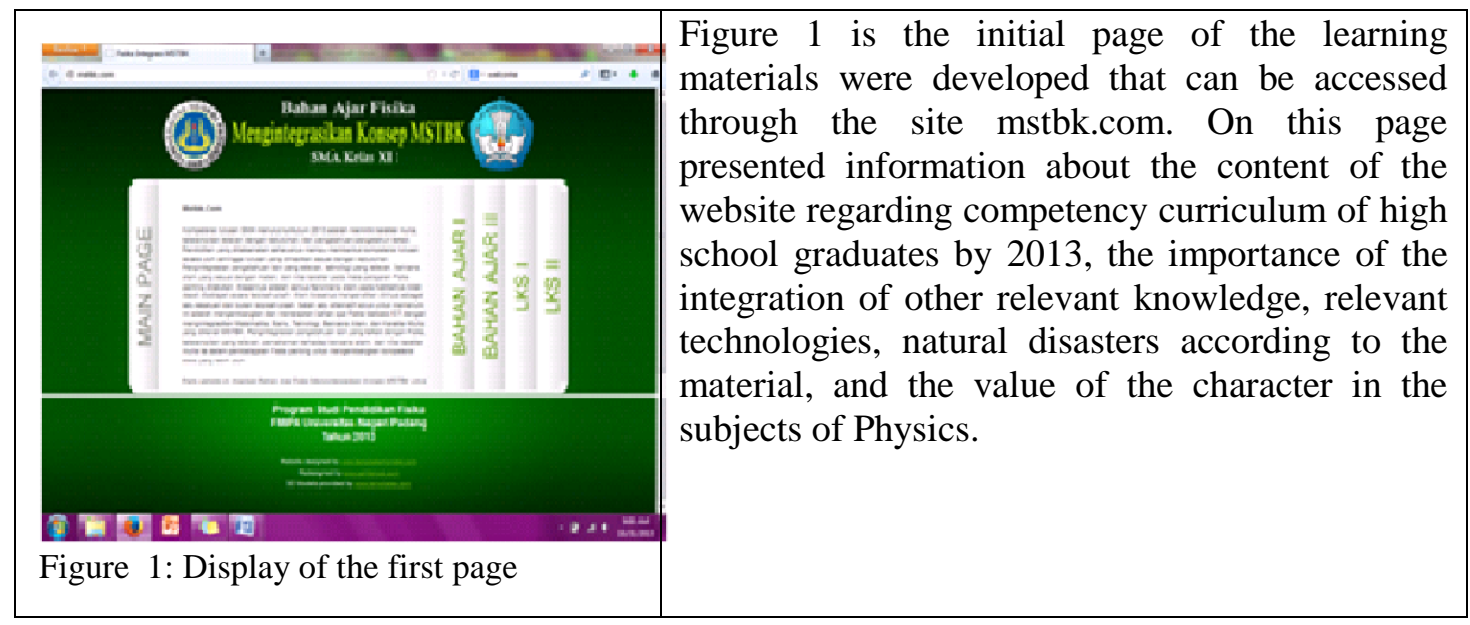

Physics contextual learning materials that integrated MSTDC base on ICT validated by a validated those two groups of experts and practitioners. As experts validate instructional materials is lecturer of Physics, State UNP while practitioners validate the teaching materials that high school physics teacher. Instructional materials that integrate contextual physics MSTDC base on ICT have been prepared in a coherent, systematic, interactive and innovative in accordance ${ }^{[16]}$. It will be easier for students to understand the learning materials are developed.

\section{b. Product Validation}

Physics contextual learning materials that integrated MSTDC base on ICT validated by professors of Physics from Padang State University as an experts. According to the validity of assessment instruments will be analyzed four components such as the substance of the material component, the display of visual communication, instructional design, and the average utilization software. The score each component of the validation can be seen in Figure 1. 


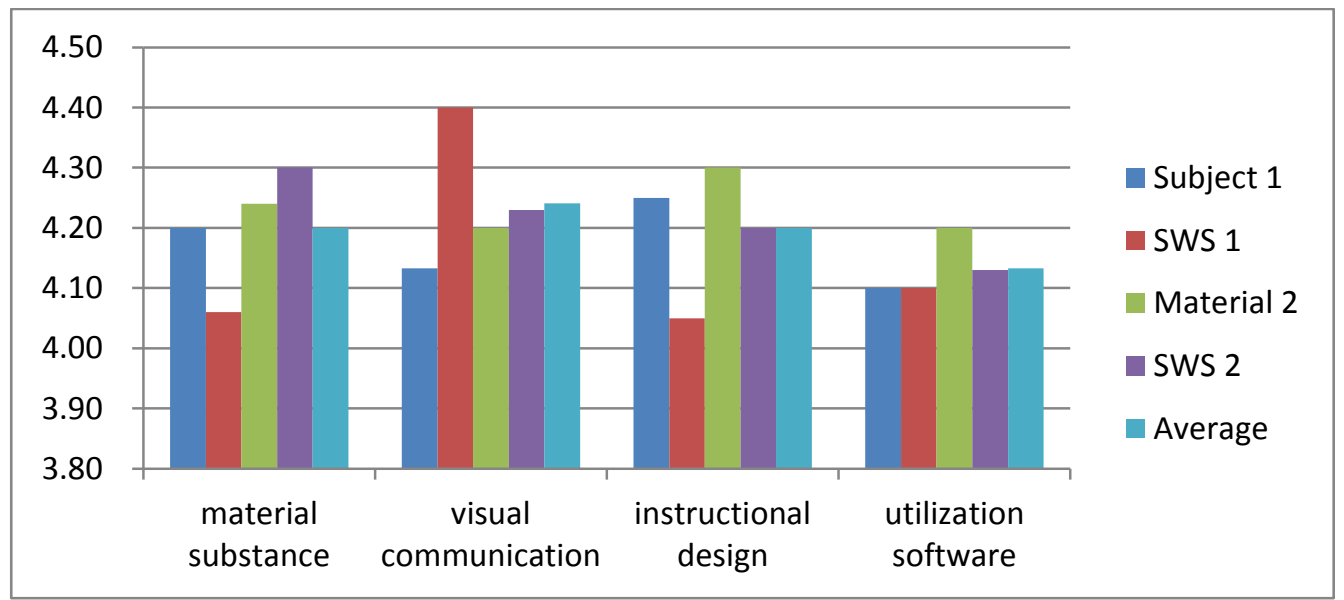

Figure 2. Average Score Validity Assessment by Experts

Description: Material is subject matter, SWS is Student Worksheet

Figure 2 shows that the substance of the material on the learning material has been well categorized. Average score validation by experts is 84.32. The validated suggestions that when this product will be used widely, the product need to some improvement such as: sentence in introduction must be made in simple sentence so that students interested in reading. Value of the character (good attitude) to be achieved by students should be presented in the introduction; it should be explained configuration integration of MSTDC in learning physics and how to enter into the learning material MSTDC.

SWS have been well categorized after the substance of the material such as Mathematics; natural disaster in learning materials was revision. The other part, such as the display of visual communications, proportional font and color composition and the use of video was developed. After validation carried out by experts from the faculty of the Department of Physics Padang State University, validation was under taken by physics senior high school teacher. Physics teachers validate about practicality and possibility of these products can be used in senior high school. Physics teacher who validate that has been experienced in the teaching 5 years until the teacher has more than 20 years with the educational background of Bachelor of Education.

Data shows that the easy to use of the menu got an average score of 4.43 , well categorized. It means that the menus system has been made can be operated easily by the users of this product. The same thing applies to easy to use a guide with a score of 4.28 , well categorized. It means that the guide can guide the user to use the product properly. Score 4.25 ease of use of multimedia is well categorized. Despite the ease of use of multimedia well categorized, considering only scores 4.25 , the ease of using multimedia needs to be improved, especially in the use of video and animation before the product is used in learning on a wide scale. Then score the easy to use of the assessment system was 4.23, good categories. It means that the assessment system using in this product are ready to use. Senior high school Physics teacher agreed that the learning materials by integrating MSTBK base ICT is very helpful to achieve student's competence in senior high school on class XI. This indicates that the applicability of products in the learning process will be a high. So in general has to be said that contextual Physics learning materials by integrating MSTDC base on ICT for senior high school students have good quality when viewed from theoretical and practical view. Of course it is very necessary level tested practicalities and effectiveness to real users, namely students 
c. The effectiveness of Learning Materials Integrate MSTBK Base on ICT

The effectiveness of instructional materials integrates MSTBK based on ICT analyzed from two aspects. Aspects are student learning outcomes and student character (attitude value). Test the effectiveness of student learning outcomes were analyzed by using a significance difference between learning outcomes before and after the use of instructional materials. Base on data analysis from the score pretest and posttest learning outcome using the equation product moment correlation is obtained coefficient correlation $\left(\mathrm{r}_{\mathrm{xy}}\right)=0.31$. The result of calculation of differences learning outcomes of student at pretest and posttest which is used $t_{\text {test }}$ formula is obtained $\mathrm{t}$ correlated $\left(\mathrm{t}_{\text {count }}\right)=1.91$. The number of respondents in the research was 121 students. It means we use statistical degrees of freedom is 120 . Critical value "t" on the table which degrees of freedom (df) $=120$ and a significance level $5 \%$ is 1.66 . This data show that $t_{\text {count }}$ greater than $t_{\text {table. }}$ It means contextual Physics learning materials that integrated MSTDC base on ICT effectively used in the learning process according to standards to improve learning outcomes of high school students in class XI. This result agrees with Stanbrough: 2009) that said learners should be taught to use and apply the English/mathematics/ICT that they know and to ask for help with the areas with which they are less confident.

Observation of the value of the character (attitude) students conducted before and during the learning activities using contextual Physics learning materials that integrated MSTDC base on ICT. Attitude of students were observed during the learning activities using contextual Physics learning materials that integrated MSTDC base on ICT, namely: religious, honest, curiosity, like to read, friendly, cooperation, discipline, and responsibility. The results of calculation value of $\mathrm{t}$ for different the attitude of students after treatment with before treatment using t-test formula correlated are 12.42. Value criticism " $\mathrm{t}$ " that the degrees of freedom $(\mathrm{df})=120$ and a significance level $=5 \%$ in the distribution table is 1.66 . Value of $\mathrm{t}_{\text {count }}$ in calculation is greater than the $t_{\text {table. }}$. This shows that there is a significant difference between the attitude of students before and after using the learning materials. So it can be concluded that contextual Physics learning materials that integrated MSTDC base on ICT effectively used in learning to improve the attitude of senior high school students at class XI. Attitude is the deliberate effort to help people understand, how about, and act upon core ethical values ${ }^{[21],[25],[20]}$

Based on the analysis of two aspects of the assessment of effectiveness of learning materials we can be concluded that contextual Physics learning materials that integrated MSTDC base on ICT effectively used physics learning to improve learning outcomes and to improve student character value in senior high school in class XI. Implementation of learning using contextual Physics learning materials that integrated MSTDC base on ICT in learning physics in the class XI still find some obstacles such as the limited number of active computers in the laboratory, the limited loading speed internet access and the ability of senior high school physics teachers uses the computer laboratory for learning physics.

\section{CONCLUSIONS AND RECOMMENDATIONS}

a. Conclusion

Based on the research and discussion that has been done, we can make some conclusions as follows:

1. Contextual Physics learning materials that integrated MSTDC base on ICT can be used to support the learning process to reach students competence in senior high school in class XI. The main menu consist of identity, introduction, learning materials, training, 
evaluation, reference, download, chat, and discussion boards are equipped with multimedia elements that making it more interactive and interesting for learning.

2. Accordance with research objectives that is to develop contextual Physics learning materials that integrated MSTBK base on ICT for senior high school students that has good validity, we can be revealed that this learning material is well categorized in four categories of assessment such as the material substance, display visual communication, learning and use of software design.

3. Based on the analysis of practicality of learning materials we can be concluded that contextual Physics learning materials that integrated MSTDC base on ICT practice was used for physics learning to improve learning outcomes and to improve student character value in senior high school in class XI

4. Based on the analysis of two aspects of the assessment of effectiveness of learning materials we can be concluded that contextual Physics learning materials that integrated MSTDC base on ICT effectively used physics learning to improve learning outcomes and to improve student character value in senior high school in class XI

b. Recommendations

Based on the results obtained in this study suggested the following matters:

1. Integrating MSTDC must be to improve in the animation, the writing of the amount of Physics, facilities for student responses.

2. The learning materials should be developed for other subject matter, so that students can easily find learning materials anytime, anywhere and in any condition.

3. High School Physics Teachers can use contextual Physics learning materials that integrated MSTDC base on ICT to achieve student Physics competence in senior high school in class XI as one alternative to the use of ICT in the teaching of physics in schools.

4. Students can take advantage of contextual Physics learning materials that integrated MSTDC base on ICT as a source of learning to improve knowledge, attitudes, and skills in learning physics.

5. In operating contextual Physics learning materials that integrated MSTDC base on ICT need adequate internet network. According to this condition, school leaders need to develop adequate internet network so that the use of ICT for learning can be optimized. Another alternative to do is use a modem to facilitate the use of ICT in learning

\section{Bibliography}

[1] Akmam dan Harman Amir. 2013. Pengembangan Bahan Ajar Kontekstual Berbasis ICT dengan Mengintegrasikan Konsep MSTBK untuk Mencapai Kompetensi Fisika Kelas XI SMA. Padang: UNP

[2] Abdul, G, (2004). Pedoman Khusus Penyusunan Materi Pembelajaran (Instructional Materials). Direktoral Jenderal Pendidikan Dasar dan Menengah, Jakarta. 
Akmam et.al. / The Effectiveness Using ...

ISBN $978-979-99314-8-1$

[3] Afno khoji, Afnai Niskarsa, (2011). Relationship Between Physics and Biology. http://nepalcsi.blogspot.com/2011/01/relationship-between-physics-and.html

[4] Akhmad Sudrajad, (2008). Pengembangan Indikator Pencapaian Kompetensi Dasar. http://akhmadsudrajat.wordpress.com/2008/08/15/pengembangan-indikator-dalam-ktsp.

[5] Andi Prastowo. 2011. Panduan Kreatif Membuat Bahan Ajar Inovatif Menciptakan Metode Pembelajaran yang Menarik dan Menyenangkan. Jogjakarta: Diva Press

[6] Andrew Zimmerman Jones, (2011). Mathematics and Physics. About.com Guide April 4, 2011 http://physics.about.com/b/2011/04/04/mathematics-and-physics.htm.

[7] Asmaran As. 1994. Pengantar Studi Akhlak. Jakarta : Raja Grafindo. cetakan. ke-2

[8] Bambang Ruwanto. 2009. Gagasan Mengajarkan Fisika Matematika di SMA. Yogyakarta: FMIPA UNY

[9] Bambang, S, (2007). Materi Sosialisasi dan pelatihan Kurikulum Tingkat satuan Pendidikan (KTSP) SMA. Departemen Pendidikan Nasional, Jakarta.

[10] Cheppy Riana, (2008). Pengembangan Bahan Ajar Berbasis ICT di Sekolah: Membantu Mewujudkan Sekolah yang Berstandar dan Bermutu. http://cepiriyana.blogspot.com/ 2008/11/peningkatan-mutu-guru-ssn-dan-sbi_06.html.

[11] Cristina, D. W, (2004). Pengaruh Penggunaan Bahan Ajar dan gaya Belajar Terhadap Hasil belajar. Artikel Pendidikan Network.

[12] Depdiknas. (2008). Panduan Pengembangan Bahan Ajar. Direktorat Jenderal Manajemen Pendidikan Dasar dan Menengah, Direktorat Pembinaan Sekolah Atas.

[13] Djoko Sukastomo. 2004. Upaya Membangun Dunia Pendidikan. Jawa Tengah: Suara Merdeka

[14] Hamzah B. Uno. 2012. Assessment Pembelajaran. Jakarta: Bumi Aksara Kementrian Pendidikan dan Kebudayaan. 2012. Bahan Uji Publik Kurikulum 2013. Jakarta: Badan Penelitian dan Pengembangan Pusat Kurikulum dan Perbukuan

[15] Herminarto, S, (1997). Pengembangan bahan Ajar Sekolah Kejuruan (SMK). Fakultas Pendidikan Teknologi dan Kejuruan Institut Keguruan dan Ilmu Pendidikan Yogyakarta.

[16] Ibnu Fajar, (2010). Panduan Penyusunan Bahan Ajar Berbasis TIK. Informasi Pendidikan, Berbagai informasi berbagai dunia pendidikan, profesi keguruan, kemajuan ilmu pengetahuan dan teknologi. http://ibnufajar75. blogspot. com/2010/06/paduan-penyusunanbahan-ajar-berbasis.html

[17] Jazuli, (2010). Panduan Bahan Ajar Berbasis TIK. http://jazuliblog.blogspot.com/2010/10/ panduan-pengembangan-bahan-ajar.html

[18] Kunandar. 2010. Guru Profesional. Jakarta: Rajawali Pers

[19] Kuswari Hernawati. 2010. Upaya Meningkatkan Ketrampilan Guru Sekolah Menengah di Daerah Istimewa Yogyakarta dalam Pembuatan Sumber Belajar Matematika Berbasis Web. Yogyakarta: Jurusan Pendidikan Matematika FMIPA UNY

[20] Marshall, Stave (2004). Choosing and using teaching and learning materials, The State of South Australia, Department of Education and Children's Services Produced by DECS Publishing.

[21] Muhammad Asrori Ardiansyah, (2011). Konsep Pendidikan Karakter. Artikel Pendidikan, Pendidik http://www.majalahpendidikan.com/2011/05/artikel-pendidikan-konseppendidikan. html. 
[22] Mulyasa. 2006. Kurikulum Tingkat Satuan Pendidikan Suatu Pendekatan Praktis. Bandung: Remaja Rosda Karya

[23] Nana Sudjana. 2001. Penilaian Hasil Belajar Mengajar. Bandung: Remaja Rosdakarya

[24] Sofan Amri. 2011. Implementasi Pendidikan Karakter dalam Pembelajaran. Surabaya: Prestasi Pustaka

[25] Sri Handayani dan Ari Damari. 2009. Fisika untuk SMA dan MA Kelas XI.Jakarta: Pusat Perbukuan Depdiknas

[26] Stanbrough. 2009. The Role of Mathematics in Physics.http://batesvilleinschools.com/ Physics/ phynet/aboutsciences/role_of_math.html

[27] Sugiyono. 2012. Metode Penelitian Pendidikan. Bandung:Alfabeta

[28] Suharsimi Arikunto. 2010. Prosedur Penelitian. Jakarta:Bumi Aksara

[29] Sulipan, (2009). Struktur Bahan Ajar/ Modul. EDC Bandung. http://www.oocities. org/ pengembangan_sekolah/kumpulan2.html

[30] Sungkowo M. 2010. Panduan Pengembangan Bahan Ajar Berbasis TIK. Jakarta: Kementrian Pendidikan Nasional

[31] Susilowati. 2012. Pemanfaatan Internet Sebagai Sumber Belajar. Disampaikan pada Kegiatan PPM, Sabtu 10 November 2012 : FMIPA UNY

[32] Sutarjo Adisusilo. 2012. Pembelajaran Nilai-Karakter. Jakarta:PT RajaGrafindo Persada

[33] Sutardi, (2010). Pengembangan Bahan Ajar Fisika SMA Berbasis Spreadsheet Untuk Meningkatkan Kemampuan Siswa Berkomunikasi Ilmiah. SMA 5 Semarang Jln. Pemuda 143 Semarang, Proseding Pertemuan Ilmiah XXIV HFI Jateng \& DIY

[34] Sutrisno. 2006. Fisika dan Pembelajarannya. Bandung: FPMIPA UNP

[35] Suyanto. 2009. Urgensi Pendidikan Karakter. Direktorat Jendral Manajemen Pendidikan Dasar dan Menengah, http://mandikdasmen.kemdiknas.go.id/ web/pages/urgensi.html

[36] Trefill, James dan Hazen Robert. 2007. The Sciences An Integrated Approach. USA : John Willey and Sons, Inc.

[37] Trianto. 2012. Model Pembelajaran Terpadu. Jakarta: Bumi Aksara

[38] Wagiran, (2011).Developing Technical Vocational and Training (TVET) Student Character Through School Culture. Makalah Seminar Nasional IKA UNY, Technical Faculty, Yogyakarta State University.

[39] Wawan Hartanto, (2010). Membuat Bahan Ajar Berbasis ICT Memakai Powerpoint. http://www.docstoc.com/docs/2060382/Membuat-Bahan-Ajar-Berbasis-ICT

[40] Wina Sanjaya. 2006. Strategi Pembelajaran Berorientasi Standar Proses Pendidikan. Jakarta: Kencana

[41] Wikipedia, the free encyclopedia on-line : 2013

[42] Zulfina, P, (2004). Pendidikan yang Memberlakukan Kurikulum Berbasis Kompetensi (KBK). All Right Reserved. 
PE-12 